steering committee that certain topics are taboo may discourage members in their treatment of permitted topics); of chairmanship competent to create a confidence that dispels national suspicions and individual timidity and promotes an easy interchange of opinion; of the proper use of "experts," so that exact knowledge shall be available but shall be restrained from suffocating discussion or antagonizing the "practical" men and women of affairs; of prior arrangement, calculated to stimulate preparedness on the part of all members; ete. For the student of international procedure, the opportunity to consider these aspects of an Institute conference is as profitable as that of participating in discussions of the profoundly difficult and important subjects which appear upon the conference agenda.

\title{
University of Minnesota.
}

Harold S. Quigley.

Personnel of Republican and Democratic National Committees. The following analysis of the membership of the Republican and Democratic national committees for the term 1928-32 is intended as a preliminary statement of a detailed analysis which will portray American party organization in more definite terms than have hitherto been applied. The data were taken from Who's Who in America, Biographical Directory of the United States Congress, official state handbooks, and such specialized sources as the Directory of Directors, Who's Who in Government, and regional directories. It has been found necessary to exclude from the study the women members of the committees, since information concerning them could not be secured. Consequently, the analysis is confined to the 108 men, one from each state for each party and twelve additional "executive" members, who direct the national party organizations.

Age of committeemen. An average age of 58.1 years would seem to indicate that party managers represent greater experience, in terms of age at least, than most public officials. Republican committeemen average 58.4 years, while Democratic committeemen average 58 years. The oldest, a Democrat, is 86 ; the youngest, a Republican, is 43 .

Education. Approximately thirty-eight per cent, or 41 members, have had educational training of college rank. Of these, 39 have degrees. LL.B. degrees head the list with 19 ; A.B., 8 ; M.A., 5 ; M.D., 3 ; B.S., 3 ; C.E., 1. The two parties are on essentially equal terms, the Republicans being represented by 21 members, the Democrats by 20 .

Membership in Fraternal Orders. Fifty-three committeemen are recorded as members of fraternal orders. Of these, 34 are Republicans and 19 Democrats. The distribution of membership in the various orders is as follows: 


\begin{tabular}{|c|c|c|}
\hline Repul & eblicans & Democrats \\
\hline Masons $\ldots \ldots \ldots \ldots \ldots \ldots \ldots \ldots \ldots \ldots$ & 30 & 12 \\
\hline Elks $\ldots \ldots \ldots \ldots \ldots \ldots \ldots \ldots \ldots \ldots 1$ & 13 & 8 \\
\hline 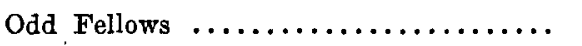 & 8 & 2 \\
\hline Knights of Pythias ................. & 5 & 3 \\
\hline Knights of Columbus ............... & & $\mathbf{5}$ \\
\hline Jr. O.U.A.M. $\ldots \ldots \ldots \ldots \ldots \ldots \ldots \ldots$ & 2 & \\
\hline Moose $\ldots \ldots \ldots \ldots \ldots \ldots \ldots \ldots \ldots$ & & 1 \\
\hline
\end{tabular}

Religious Affiliations. Sixty-three members list their religious affiliations as follows:

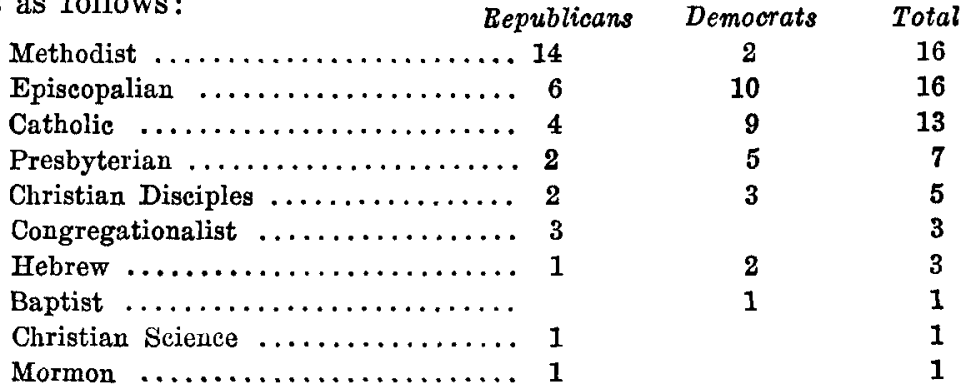

Political Experience. The average member of a national committee has served 8 years in that capacity. The average Republican member has served 9.2 years, while the average Democrat has seen 7.7 years in his office. To this experience, the average Republican member adds 14 years as a member of his state central committee, though the average Democrat has spent but 5 years in that position. In addition, the average Republican has held public office 9.6 years and the average Democrat 10.5 years.

Economic Interests and Alliances. No other item of information is so significant as the relation of the managers of party activity to those powerful pressure groups who represent certain well-defined economic interests. Whereas various considerations often force these groups to adopt the cloak of anonymity in other fields of political life, the following table seems to indicate that their control in party organization is not subject to any such limitation.

\begin{tabular}{|c|c|c|}
\hline Republicans & Democrats & Total \\
\hline Banking and insurance $\ldots \ldots \ldots \ldots \ldots, 31$ & 16 & 47 \\
\hline Railroads and other utilities ....... 13 & 7 & 20 \\
\hline Manufacturing $\ldots \ldots \ldots \ldots \ldots \ldots \ldots$ 13 & 4 & 17 \\
\hline Publishing $. . . \ldots \ldots \ldots \ldots \ldots \ldots, \quad 2$ & 7 & 9 \\
\hline Oil $\ldots \ldots \ldots \ldots \ldots \ldots \ldots \ldots \ldots \ldots, \quad 4$ & 1 & 5 \\
\hline Coal $\ldots \ldots \ldots \ldots \ldots \ldots \ldots \ldots \ldots \ldots, 4$ & & 4 \\
\hline Lumber $\ldots \ldots \ldots \ldots \ldots \ldots \ldots \ldots \ldots, \quad 3$ & & 3 \\
\hline Realty $\ldots \ldots \ldots \ldots \ldots \ldots \ldots \ldots \ldots, 1$ & 2 & 3 \\
\hline Cattle and sheep $\ldots \ldots \ldots \ldots \ldots \ldots, 4$ & 4 & 8 \\
\hline Whert-farming $\ldots \ldots \ldots \ldots \ldots \ldots \ldots 1$ & & 1 \\
\hline Orchards $\quad \ldots \ldots \ldots \ldots \ldots \ldots \ldots \ldots$ & 1 & 1 \\
\hline Law $\ldots \ldots \ldots \ldots \ldots \ldots \ldots \ldots \ldots \ldots, 20$ & 24 & 44 \\
\hline
\end{tabular}


The business-man's control of national party organization is here clearly illustrated. Even the lawyer, who has so often dominated the American political scene, is submerged; for of the 44 members of the bar listed above, only 19 are engaged exclusively in the practice of the profession. The others are actively occupied with one or more of the business enterprises included in the table. Agriculture is not directly represented by any member, for the lone wheat-farmer is really a business man managing a 10,000-acre enterprise, and the cattle and sheep representatives combine banking with their activities. Labor has not even an indirect representation.

Sectional Aspects of Economic Interests. The relation between economic forces and party organization is even more striking when the data are arranged sectionally. If we use Professor Holcombe's familiar division of the United States into ten politico-economic sections, we find that the business-man predominates in every section except in the lower South and the west-central states. In these two, his control is shared by the lawyer, who is often associated with him as counsel or partner. Banking and insurance exercise a controlling influence in all but these two sections, and even here it is a close second.

WALLACE S. SAYRE.

New York University. 